\title{
菌血症が疑われた患者に対する Tazobactam/Piperacillin長時間投与の有効性
}

\author{
上田真也 ${ }^{* 1,3}$, 深見和宏 ${ }^{1}$, 薄 雅人 ${ }^{1}$, 岡崎貴裕 ${ }^{2.3}$ \\ 独立行政法人国立病院機構静岡医療センター 薬剤部 \\ 独立行政法人国立病院機構静岡医療センターリウマチ・膠原病内科 ${ }^{2}$ \\ 独立行政法人国立病院機構静岡医療センター 感染対策室 ${ }^{3}$

\section{Efficacy of the Extended Administration of Tazobactam/Piperacillin for Patients with Suspected Bacteremia}

\author{
Shinya Ueda ${ }^{* 1,3}$, Kazuhiro Fukami ${ }^{1}$, Masato Usuki and Takahiro Okazakii ${ }^{2.3}$ \\ Department of Pharmacy, National Hospital Organization Shizuoka Medical Center ${ }^{1}$, \\ Department of Rheumatology and Connective Tissue Diseases, National Hospital Organization Shizuoka Medical Center ${ }^{2}$, \\ Department of Infection Control, National Hospital Organization Shizuoka Medical Center ${ }^{3}$

$$
\left[\begin{array}{l}
\text { Received November 25, } 2019 \\
\text { Accepted March 23, } 2020
\end{array}\right]
$$

The methods of administering the chemical antibiotic agent TAZ/PIPC were investigated through PK/PD analysis, in order to promote an improved efficacy of the drug. The subjects were patients with suspected bacteremia who received rapid $(30-60 \mathrm{~min}, \mathrm{n}=24)$ and extended $(4 \mathrm{hr}, \mathrm{n}=33)$ administrations of TAZ/PIPC. The clinical outcomes in the two groups were analyzed and compared to evaluate the efficacy of the two methods of administration. An analysis of WBC, CRP, and body temperature on the 7 - 9th day of administration revealed no significant difference between the two groups in terms of the decrease in each parameter. However, $67 \%$ of the patients with a SIRS score $\geqq 3$ in the extended administration $(n=18)$ group showed improvement in at least two of the three parameters, compared to only $33 \%$ of those in the rapid administration group $(\mathrm{n}=12)$. Thus, there was a marginally higher rate of improvement in the extended administration group $(P=0.073)$ than in the rapid administration group. Similarly, among the patients with a SIRS score $\geq 3$, CRP improved significantly in the extended administration group on the $7-9$ th day of administration $(P=0.0042)$. These results suggest that extended administration of TAZ/PIPC may improve clinical outcomes more effectively than rapid administration in patients with severe bacteremia.

Key words — TAZ/PIPC, extended administration, PK/PD, SIRS score

\section{緒言}

Tazobactam/piperacillin（TAZ/PIPC）は, 広域で かつ強力な抗菌力を有しており，優れた臨床効果 を示す薬剤である. ${ }^{1)}$ Pharmacokinetics/pharmacodynamics（PK/PD）理論からすると TAZ/PIPCの効 果は時間依存性殺菌作用であるため, Time above minimum inhibitory concentration (MIC) が重要な パラメータとなる. そのため, 1 日の投与回数を
増やすことや 1 回投与時間を延長することにより Time above MIC を増加させる方法が有用と考え られる. TAZ/PIPC はペニシリン系抗菌薬であり, Time above MIC が投与間隔時間の $30 \%$ 以上で増 殖抑制作用， $50 \%$ で最大殺菌作用を示すことが報 告されている. ${ }^{2)}$ た, 2015 年にはTAZ/PIPCに ついて, 9つの観察研究および5つのランダム化 試験の結果に基づいたメ夕解析が公表されてお り, 臨床的な有用性, あるいは死亡率の低減とい

\footnotetext{
* 个411-8611 静岡県駿東郡清水町長沢762-1
} 
う点で従来の点滴投与法と比較した場合, 点滴時 間の延長または持続点滴が優れていることが示さ れている. ${ }^{3)}$ しかし,これらの報告にもかかわらず， 日本人を対象とした検討や検査值の変化の解析研 究は少ない. 今回, 我々は TAZ/PIPCの Time above MIC の $50 \%$ 達成確率が 4 時間持続投与により上 昇するという報告 ${ }^{4}$ をを基に，通常の点滴による短 時間投与（30-60 分）群と長時間投与（4 時間） 群に大別して TAZ/PIPC を投与された症例を後方 視的に解析し, 日本人における $\mathrm{PK} / \mathrm{PD}$ 理論に基 づいた TAZ/PIPCの投与方法の有用性を検討した.

\section{方 法}

\section{1. 調查対象}

独立行政法人国立病院機構静岡医療センター心 臓血管外科病棟にて, 菌血症を疑い血液培養検査 を提出し，TAZ/PIPCの単剂投与を開始した日本 人患者を対象とした。ただし，除外基準として， ほかの抗菌薬による前治療や併用療法を行った場 合，心臓血管外科病棟以外への途中転棟などがあ る場合, TAZ/PIPC 投与量が, 添付文書・サンフォー ド治療ガイド・JAID/JSC 感染症治療ガイドなどに 準じていない場合，TAZ/PIPCによる副作用が疑 われ中止・変更となった場合，解熱剂を定期使用 している場合（頓用を除く）, TAZ/PIPCに感受性 のない methicillcin resistance Staphylococcus aureus （MRSA）等の菌種が血液培養検査により検出さ れ，かつ抗 MRSA 薬等の抗菌薬へ変更した場合 （感受性のない菌が検出されたが医師の判断によ り，検出菌を治療対象とせず TAZ/PIPCを継続し た例は除外せず)，を設定しこれらを対象より除 外した。

また，重症敗血症の半数は細菌培養検査陰性で あったという報告 ${ }^{5)}$ や，菌血症であっても血液培 養検査から病原菌を検出する確率は 5.2 $15.1 \%$ と必ずしも高くなく，またコンタミネーション率 は $1.0 \sim 6.3 \%$ と報告 ${ }^{6.7)}$ があるため, 血液培養検 查陰性例を区別せず，調査を行った。

\section{2. 分類およびデータの抽出}

TAZ/PIPC の 4 時間投与を行った症例（2015 年
10 月〜2016 年 9 月）を長時間投与群, $30-60$ 分 投与を行った症例（2014 年 10 月〜2015 年 9 月） を短時間投与群とし，後方視的に調査した。

調查項目は年齢, 性別, 体重, creatinine clearance (Ccr), white blood cell (WBC), C-reactive protein (CRP)，1 日最高体温 (体温), 呼吸数, 心拍数, 投与日数, 入院原疾患, TAZ/PIPC1 回投与量およ び 1 日投与回数とした。 また，全身状態の評価と して systemic inflammatory response syndrome （SIRS）の評価を用いた。すなわち，1）体温 > $38^{\circ} \mathrm{C}$ まは $<36^{\circ} \mathrm{C}$ ，2）心拍数 $>90 / \mathrm{min}$, 3）呼 吸数 $>20 / \mathrm{min}$ または $\mathrm{PaCO}_{2}<32$ Torr, 4）末梢血 白血球数 $>12,000 / \mu \mathrm{L}$ または $<4,000 / \mu \mathrm{L}$, あるい は未熟型白血球 > 10\%のうち満たしている項目 数でスコア化（SIRS score）した.

TAZ/PIPC 投与開始後 7-9 日目に「呼吸器感染 症における新規抗微生物薬の臨床評価法」におけ る臨床評価基準 ${ }^{8}$ を満たした場合を臨床的改善と し, 改善した人数の割合を臨床的改善率とした. すなわち，(1) CRP が介入開始前の值に対し $70 \%$ 以上の低下, (2) WBC の 8,000/ $\mu \mathrm{L}$ 未満への減少, (3)体温 $37^{\circ} \mathrm{C}$ 未満への低下, の 3 項目のうち 2 項 目以上の条件を満たし, かつ残りの 1 項目の増悪 がみられない場合を臨床的改善とした。また, 症 例のうち SIRS score 3 以上の重症度の高い症例に ついても投与期間, 臨床的改善率, 検查值の変動 について解析を行った.

\section{3. 統計学的解析}

統計学的解析は, Excel 統計を用いて行った. Student $の t$ 検定, Fisher の正確確率検定, MannWhitney $U$ 検定, Wilcoxon 順位和検定, 多重ロジ スティック回帰分析を用い, $P<0.05$ を統計学的 有意水準として有意差ありと判定し, $P=0.05-$ 0.10 を有意差はないものの, 傾向ありと判定した.

\section{4. 倫理的配慮}

本研究の実施にあたっては, 独立行政法人国立 病院機構静岡医療センター臨床研究審査委員会の 承認（承認番号 17-13）を得て「人を対象とする 医学系研究に関する倫理指針」を遵守して実施し た。 


\section{結果}

\section{1. 患者背景}

短時間投与群は 24 例, 長時間投与群は 33 例で あった，背景因子としての治療開始時の年齢，性 別, 体重, Ccr, WBC, CRP, 体温, SIRS score のそれぞれについて, 群間差は認められなかった. 投与日数については短時間投与群で平均 11.0 日, 長時間投与群で平均 7.9 日と短縮傾向がみられた $（ P=0.057 ） （$ 表 1)。 また，入院原疾患は短時間 投与群と長時間投与群では上位疾患に大きな違い はなかった（表 2).

\section{2. 血液培養検査からの検出菌比較}

短時間投与群では検出菌数 14 であり検出され た菌は methicillcin resistance Staphylococcus epidermidis (MRSE) 3 例, Escherichia coli (E. coli) 2 例, methicillcin susceptible Staphylococcus aureus （MSSA） 1 例, MRSA 1 例, Klebsiella 1 例, Enterococcus 1 例, Bacillus 1 例, Enterobacter 1 例, Citrobacter 1 例, Pseudomonas aeruginosa 1 例,
Stenotrophomonas maltophilia 1 例が検出され培養 侩性は 14 例であった。長時間投与群では検出菌 数 18 であり検出された内訳で主な菌は MRSE 6 例, E. coli 2 例, MSSA 2 例, MRSA 2 例, Klebsiella 2 例, Enterococcus 1 例, Bacillus 1 例, Enterobacter 1 例, Corynebacterium 1 例が検出さ れ培養陰性は 15 例であった。両群での検出菌に ついて，上位菌種に大きな違いはなかった（検出 菌数は同一の血液培養検査から数種類の検出を含 む）(表 3).

\section{3. 臨床的改善}

体温の改善は短時間投与群で $50 \%$ （12 例）, 長時間投与群で 64\%（21 例), WBC の改善は短 時間投与群で $50 \%$ （12 例）, 長時間投与群で $67 \%$ (22 例), CRP の改善は短時間投与群で $38 \%$ （9例)，長時間投与群で 39\%（13 例）であ り, 臨床的改善率は短時間投与群で $42 \%$ （10 例）, 長時間投与群で $61 \%$ （20 例）と $19 \%$ の上昇がみ られたが, すべての評価項目について有意差は認 められなかった（表 4).

表 1 患者背景

\begin{tabular}{|c|c|c|c|}
\hline 項目 & 短時間投与群 $(n=24)^{a)}$ & 長時間投与群 $(n=33)^{a)}$ & $P$ P值 ${ }^{\mathrm{b})}$ \\
\hline 年齢（歳） & $74 \pm 14.3$ & $74 \pm 9.3$ & 0.269 \\
\hline 性別 (女性)c） & $10(42)$ & $12(36)$ & 0.785 \\
\hline 体重（kg） & $59 \pm 19.0$ & $54 \pm 13.2$ & 0.269 \\
\hline CRP $(\mathrm{mg} / \mathrm{dL})$ & $13.0 \pm 8.7$ & $12.9 \pm 9.9$ & 0.897 \\
\hline WBC $\left(\times 10^{2} / \mu \mathrm{L}\right)$ & $125 \pm 47.9$ & $110 \pm 50.4$ & 0.181 \\
\hline $\operatorname{Ccr}(\mathrm{mL} / \mathrm{min})$ & $63 \pm 47.9$ & $44 \pm 31.0$ & 0.103 \\
\hline 体温（ ${ }^{\circ} \mathrm{C} ）$ & $38.2 \pm 1.13$ & $38.3 \pm 0.85$ & 0.651 \\
\hline SIRS score & $2.0 \pm 1.12$ & $2.5 \pm 0.78$ & 0.864 \\
\hline 投与日数（日） & $11.0 \pm 5.5$ & $7.9 \pm 3.4$ & 0.057 \\
\hline 1 回投与量 $(\mathrm{g})$ & 4.5 & 4.5 & \\
\hline 1 日投与回数 (2 回 / 3 回 / 4 回) & $1 / 20 / 3$ & $4 / 25 / 4$ & 0.435 \\
\hline
\end{tabular}

a) 数值は平均 \pm 標準偏差. b) 年齢, 体重は Student の $t$ 検定, 性別, 1 日投与回数は Fisher の正確確率検定, CRP, WBC, 体温は Mann-Whitney $U$ 検定. c) 数值は人数, ( ) 内は\%. CRP: C-reactive protein, WBC: white blood cell, Ccr: creatinine clearance, SIRS: systemic inflammatory response syndrome.

表 2 入院原疾患

\begin{tabular}{lcc}
\hline \multicolumn{1}{c}{ 病名 } & 短時間投与群 $(\mathrm{n}=24)^{\mathrm{a})}$ & 長時間投与群 $(\mathrm{n}=33)^{\mathrm{a})}$ \\
\hline 急性大動脈解離 & 6 & 10 \\
胸・腹部大動脈瘤 & 6 & 9 \\
弁閉鎖不全症 & 4 & 4 \\
心不全 & 2 & 5 \\
閉塞性動脈硬化症 & 2 & 1 \\
その他 & $4^{\mathrm{b})}$ & $4^{\mathrm{c})}$ \\
\hline
\end{tabular}

a) 数值は件数. b ) ペースメーカー埋め达み, 哚部静脈血栓症, 蜂窩織炎, 心蔵腫瘍. c) 心 室中隔穿孔，シャント閉塞，シャント造設，下肢静脈瘤。 
表 3 検出菌

\begin{tabular}{lcc}
\hline \hline \multicolumn{1}{c|}{ 菌名 } & 短時間投与群 $\left.\left.(\mathrm{n}=24)^{\mathrm{a}}\right)^{\mathrm{b}}\right)$ & 長時間投与群 $\left.(\mathrm{n}=33)^{\mathrm{a}}\right)^{\mathrm{b})}$ \\
\hline MRSE & 3 & 6 \\
Escherichia coli & 2 & 2 \\
MSSA & 1 & 2 \\
MRSA & 1 & 2 \\
Klebsiella & 1 & 2 \\
Enterococcus & 1 & 1 \\
Enterobacter & 1 & 1 \\
Bacillus & 1 & 1 \\
Citrobacter & 1 & 0 \\
Pseudomonas aeruginosa & 1 & 0 \\
Stenotrophomonas maltophilia & 1 & 0 \\
Corynebacterium & 0 & 1 \\
陰性 & 14 & 15 \\
\hline
\end{tabular}

a) 数值は件数, b ) 検出菌数は同一の血液培養検查から数種類の検出を含む. MRSE: methicillcin resistance Staphylococcus epidermidis, MSSA: methicillcin susceptible Staphylococcus aureus, MRSA: methicillcin resistance Staphylococcus aureus.

表 4 7-9日目での臨床的改善

\begin{tabular}{|c|c|c|c|}
\hline $\begin{array}{c}\text { 全症例 } \\
\text { 項目 }\end{array}$ & 短時間投与群 $(\mathrm{n}=24)^{\mathrm{a})}$ & 長時間投与群 $\left.(n=33)^{a}\right)$ & $P$ 值 ${ }^{\mathrm{b})}$ \\
\hline $\begin{array}{l}\text { 臨床的改善率 }{ }^{c)} \\
\text { 内訳 }\end{array}$ & $42(10)$ & $61(20)$ & 0.157 \\
\hline 体温改善率 & $50(12)$ & $64(21)$ & 0.303 \\
\hline WBC 改善率 & $50(12)$ & $67(22)$ & 0.205 \\
\hline CRP 改善率 & $38(9)$ & $39(13)$ & 0.885 \\
\hline $\begin{array}{c}\text { SIRS score } 3 \text { 以 } \\
\text { 項目 }\end{array}$ & 短時間投与群 $(\mathrm{n}=12)^{\mathrm{a})}$ & 長時間投与群 $\left.(n=18)^{a}\right)$ & $P$ 值 ${ }^{\mathrm{b})}$ \\
\hline $\begin{array}{l}\left.\text { 臨床的改善率 }{ }^{c}\right) \\
\text { 内訳 }\end{array}$ & $33(4)$ & $67(12)$ & 0.073 \\
\hline 体温改善率 & $50(6)$ & $72(12)$ & 0.361 \\
\hline WBC 改善率 & $33(4)$ & $61(11)$ & 0.136 \\
\hline CRP 改善率 & $33(4)$ & $39(7)$ & 0.757 \\
\hline
\end{tabular}

a) 数值は\%, ( ) は件数. b) Fisherの正確確率検定. c) 3 項目（体温, WBC, CRP）のうち 2 項目以上の改善条件を満たし, かつ残り 1 項目の増悪がみられない場合の症例の割合. WBC: white blood cell, CRP: C-reactive protein, SIRS: systemic inflammatory response syndrome.

\section{SIRS score 3 以上の症例における臨床的改善}

上記の結果から, 我々は, より重症度が高い症 例における短時間投与群と長時間投与群について 同様の比較を試みた．SIRS score 3 以上の条件を満 たした症例は，短時間投与群で 12 例，長時間投与 群で 18 例であった（表 5)．治療開始時の年齢，性 別，体重，WBC，CRP，体温のそれぞれについて 群間差は認められなかったが，Ccrにおいては短時 間群で有意に高值であった $(P=0.014)$. 投与日数 は短時間投与群で平均 9.3 日, 長時間投与群で平均 8.6 日と有意差は認められなかった $(P=0.881)$. 体 温の改善は短時間投与群で 50\%（6 例)，長時間投 与群で $72 \%$ (12 例)，WBC の改善は短時間投与群 で 33\%（4 例）, 長時間投与群で $61 \%$ (11 例),
CRP の改善は短時間投与群で 33\%（4 例）, 長時間 投与群で 39\%（7 例）であり, 臨床的改善率は短 時間投与群で 33\%（4 例), 長時間投与群で 67\%（12 例）となり, 有意差は認めなかったものの, 長時間 投与群で良好な臨床的改善の傾向がみられた（ $P=$ 0.073）（表 4)。また，Ccrに差異があったため，臨 床的改善率について投与方法, Ccr を独立変数とし, 多重ロジスティック回帰分析を行った結果オッズ比 （95\%信頼区間）は Ccrが $1.06 （ 1.003-1.116)$, 投 与方法が 36.11（2.275 - 573.103）であった（表 6).

\section{SIRS score 3 以上の症例における個々の臨 床指標の改善}

さらに我々は，これらの重症例における個々の 
表 5 SIRS score 3 以上の患者背景

\begin{tabular}{|c|c|c|c|}
\hline 項目 & 短時間投与群 $(n=12)^{a)}$ & 長時間投与群 $(n=18)^{a)}$ & $P$ 值 $\mathrm{b})$ \\
\hline 年齢（歳） & $70 \pm 16.2$ & $73 \pm 9.5$ & 0.511 \\
\hline 性別（女性） c） & $4(33)$ & $5(28)$ & 0.745 \\
\hline 体重（kg） & $68 \pm 22.8$ & $56 \pm 14.8$ & 0.162 \\
\hline $\mathrm{CRP}(\mathrm{mg} / \mathrm{dL})$ & $14.3 \pm 10.0$ & $14.7 \pm 10.5$ & 0.866 \\
\hline $\mathrm{WBC}\left(\times 10^{2} / \mu \mathrm{L}\right)$ & $139 \pm 39.6$ & $128 \pm 55.0$ & 0.207 \\
\hline $\operatorname{Ccr}(\mathrm{mL} / \mathrm{min})$ & $85 \pm 55.6$ & $47 \pm 23.0$ & 0.014 \\
\hline 体温 $\left({ }^{\circ} \mathrm{C}\right)$ & $39.0 \pm 0.99$ & $38.7 \pm 0.61$ & 0.511 \\
\hline SIRS score & $3.3 \pm 0.49$ & $3.1 \pm 0.31$ & 0.243 \\
\hline 投与日数（日） & $9.3 \pm 4.6$ & $8.6 \pm 3.0$ & 0.881 \\
\hline 1 回投与量 $(\mathrm{g})$ & 4.5 & 4.5 & \\
\hline 1 日投与回数（2 回 / 3 回 / 4 回 $)$ & $0 / 10 / 2$ & $1 / 16 / 1$ & 0.454 \\
\hline
\end{tabular}

a) 数值は平均土標準偏差. b) 年齢, 体重はStudent の $t$ 検定, 性別, 1 日投与回数は Fisher の正確確率検定, CRP, WBC, 体温は Mann-Whitney $U$ 検定. c) 数值は人数,（）内は\%. SIRS: systemic inflammatory response syndrome, CRP: C-reactive protein, WBC: white blood cell, Ccr: creatinine clearance.

表 6 SIRS score 3 以上の症例における Ccr と投与方法の臨床的改善率への影響

\begin{tabular}{lccc}
\hline \hline & オッズ比 ${ }^{\mathrm{a})}$ & $95 \%$ 信頼区間 ${ }^{\mathrm{a})}$ & $P$ 值 $^{\mathrm{a})}$ \\
\hline $\mathrm{Ccr}(\mathrm{mL} / \mathrm{min})$ & 1.06 & $1.003-1.116$ & 0.037 \\
投与方法 $^{\mathrm{b})}$ & 36.11 & $2.275-573.103$ & 0.011 \\
\hline
\end{tabular}

a）多重ロジスティック回帰分析．b）投与方法（短時間投与，長時間投与)。SIRS: systemic inflammatory response syndrome, Ccr: creatinine clearance.
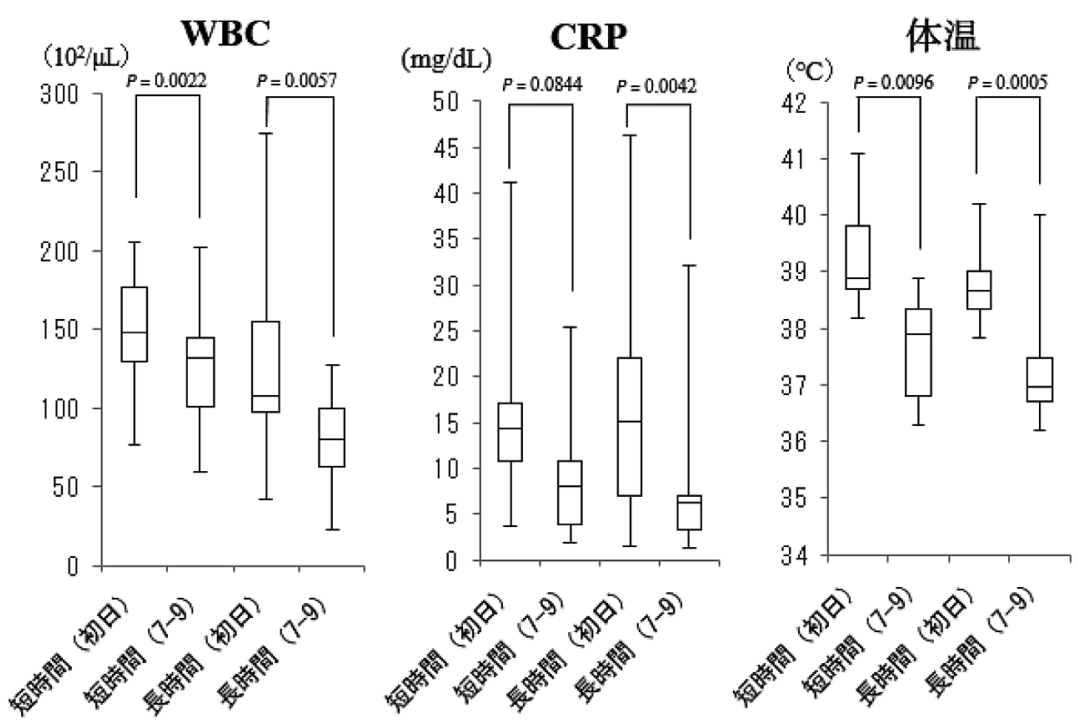

図 1 SIRS score 3 以上の症例における WBC, CRP, 体温の変化 エラーバーは標準偏差を示す．Wilcoxon 順位和検定. SIRS: systemic inflammatory response syndrome, WBC: white blood cell, CRP: C-reactive protein.

検査指標の経時的改善度に関して，治療初日と治 療開始後 7-9 日目の検査指標を抽出し，群間・ 群内で変化の比較を試みた．WBC は群内比較に おいて短時間投与群，長時間投与群ともに有意に 改善した（短時間投与群 $P=0.0022$, 長時間投与 群 $P=0.0057) . \mathrm{WBC}$ の群間比較では有意差なし $(P=0.1075)$ から長時間群で改善傾向がみられた $(P=0.0789)$. CRP は群内比較において短時間投
与群では改善に有意差はなかったが $(P=0.0844)$, 長時間投与群では有意に改善がみられた $(P=$ 0.0042). CRP の群間比較では差はなかった（ $P=$ 0.6875)。体温については短時間投与群，長時間投 与群ともに投与後 $7-9$ 日目において有意に改善 した（短時間投与群 $P=0.0096$, 長時間投与群 $P$ $=0.0005)$.また，群間比較において有意差はみ られなかった（ $P=0.4833 ）$ (図1). 


\section{考察}

$\mathrm{PK} / \mathrm{PD}$ 理論は薬物動態と薬力学を関連付ける ことにより，抗菌薬の用量・用法と作用の関係を 明らかにし, 抗菌薬の臨床効果が最大限になるべ く，抗菌薬の臨床での適正使用を実践するための 考え方である.この理論に基づいた場合，TAZ/ PIPC の効果は時間依存性殺菌作用のパラメータ と相関することが明らかになっている. ${ }^{9)}$ そのた め, 起炎菌に対する有効濃度の持続時間を意味す る Time above MIC を長く確保するほど薬効を発 揮することが考えられる。すすおち，1 回の投与 量や 1 日総投与量を増加させるより, 頻回の分割 投与や投与時間を長くすることによって Time above MIC の延長を図るほうが効率的と考えられ る。ペニシリン系薬では Time above MIC50\%で

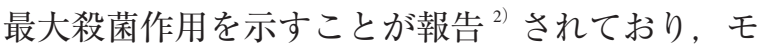
ンテカルロシミュレーションにより目標 PK/PD パラメー夕值の達成率を求めることができる.

Felton TW らは, TAZ/PIPC の Time above MIC50\% 達成率を院内感染症の入院患者の Population PK 解析からモンテカルロシミュレーションを行った ところ，8 時間毎に 30 分間投与を行うよりも 8 時間毎に 4 時間投与を行ったほうが有意に達成率 が上昇することを報告 ${ }^{4}$ している. Lodise TP Jr らの研究 ${ }^{10)}$ では, 米国緑膿菌に対するモンテカ ルロシミュレーションにて MIC = 16 の場合, 緑 膿菌に対して TAZ/PIPC $3.375 \mathrm{~g}$ を 8 時間毎に 4 時 間投与した群は Time above MIC50\% 達成率が $100 \%$ に近いのに対し，4 時間毎に 30 分間投与し た群では $50 \%$ 以下，6 時間毎に 30 分投与した群 では $30 \%$ 以下になることを示し，さらに重症度の 高い患者（APACHE II score 17 以上）では長時間 投与群では短時間投与群より有意に死亡率が低下 していた。ささらに, グラム陰性菌感染症に対して は TAZ/PIPCの 4 時間投与により重症度にかかわ らず全患者に対して死亡率の改善を示す報告 ${ }^{11}$ も されている．また，2015 年には 9 つの観察研究， 5つのランダム化試験の結果に基づくメタアナリ シス解析 ${ }^{3)}$ が公表され，持続または長時間投与に おいて臨床的治癒率および死亡率の低下という 点, 従来の点滴投与より効果が高い可能性が示さ
れており，長時間投与や持続投与に関する有用性 は今後も報告されていくと考えられる.

我々は，日本人に扔いても前述の結果が妥当で あるかどうかについて後方視的に調查を行った。 今回の結果では臨床的改善率に有意差はなかった ものの，19\%の上昇を認めたことから，長時間投 与群が優れている可能性が示唆された. しかし, それぞれの検查項目である WBC, CRP, 体温に ついて個々で比較すると投与方法にかかわらず低 下しており, 群間差は認められなかった. Lodise TP Jr らの研究 ${ }^{10)}$ でも APACHE II score 17 未満の 症例では死亡率に有意差はなかったが，APACHE II score 17 以上では死亡率の有意な低下が示され ている.今回の症例は一般病棟であり APACHE IIによる score 化ができなかったため, 代替とし て SIRS score を使用し, 症例を SIRS score 3 以上 の例に絞った場合，WBC は群間比較において有 意差なしから有意傾向に改善がみられ，CRPに ついては有意傾向の改善から有意差ありに変化し た.さらに臨床的改善率においても $34 \%$ の上昇 がみられ改善傾向であったことから TAZ/PIPC は 長時間投与が有用である可能性が示唆されるとと もに, 重症度の高い症例において長時間投与が適 している可能性が考えられた。しかし, SIRS score 3 以上の例では Ccr が短時間群で有意に高 值であった（ $P=0.0141 ）$ ため腎機能による影響 を検討し, 多重ロジスティック回帰分析を行った 結果, 投与方法の違いが腎機能によらず, 臨床的 改善率に寄与する可能性が示唆された.

また，重症度の判定についても，一般病棟入院 患者を対象としているため SIRS score のみとなっ ている. 近年は, 敗血症ガイドライン 2016 で敗 血症が疑われる例において SOFA score や qSOFA scoreによる重症度分類が推奨されている。 今回 の研究で得られた重症度が高い症例に対する TAZ/PIPC 長時間投与の妥当性を, APACHE II score や SOFA score, qSOFA score での評価を含め て検証していく必要があると考えられた.

今回は後方視的研究であり, 検出菌種に対して 起炎菌であるかを医師による判断がされていない 患者や感染臓器, デバイス関連感染の有無が判断 されていない患者が多数であった。 そのため, 培 
養陰性の症例や複数の菌種が検出されている患者 も混在している。しかし, 起炎菌による違い, 感 染臓器による違い, MICによる違い, および実 際の血中濃度も検討すべき因子である。また，今 回の研究では手術等の感染以外での検査值への影 響を考慮し, 心蔵血管外科病棟以外で TAZ/PIPC を開始した患者や投与中に転棟した場合は除外し た.これにより集中治療室等での侵襲による影響 が大きい期間や TAZ/PIPC 投与中に手術となった 患者は除外されるものの, 交絡因子の除外には限 界がある。 そのため, 今後は前向き研究で感染以 外の影響を考慮するとともに菌種や感染臓器, MIC の選別や TAZ/PIPC の血中濃度測定を実施し， 長時間投与による有効性を検討する必要がある.

\section{結論}

本研究は単施設の限られた症例数による後方視 的調査であり, 限定的な範囲ではあるが TAZ/ PIPC の PK/PD 理論に準じた長時間投与が有用で ある可能性が示唆された。本研究は報告の少ない 日本人における TAZ/PIPC の長時間投与を実臨床 で検討した貴重な報告であり，本研究が PK/PD 理論に準ずる抗菌薬適正使用の効果検証, その適 否に一石を投じる機会になることを願うものであ る. 今後も PK/PD 理論を実臨床で考慮し, 抗菌 薬の有効性に貢献する成果を発信していきたい.

\section{利益相反}

開示すべき利益相反はない.

\section{引用文献}

1) Perry C, Markham A, Piperacillin/tazobactam: an updated review of its use in the treatment of bacterial infections, Drugs, 1999, 57, 805-843.

2) Drusano GL, Prevention of resistance: a goal for dose selection for antimicrobial agents, Clin Infect Dis, 2003, 36, 42-50.

3) Yang H, Zhang C, Zhou Q, Wang Y, Chen L, Clinical outcomes with alternative dosing strategies for piperacillin/tazobactam: a systematic review and meta-analysis, PLoS One, 2015, 10, e0116769. doi: 10.1371/journal.pone.0116769.

4) Felton TW, Hope WW, Lomaestro BM, Butterfield JM, Kwa AL, Drusano GL, Lodise TP, Population pharmacokinetics of extended-infusion piperacillintazobactam in hospitalized patients with nosocomial infections, Antimicrob Agents Chemother, 2012, 56, 4087-4094.

5) Gupta S, Sakhuja A, Kumar G, McGrath E, Nanchal RS, Kashani KB, Culture-Negative Severe Sepsis: Nationwide Trends and Outcomes, Chest, 2016, 150, 1251-1259.

6) Shapiro NI, Wolfe RE, Wright SB, Moore R, Bates DW, Who needs a blood culture? A prospectively derived and validated prediction rule, J Emerg Med, 2008, 35, 255-264.

7) Wildi K, Tschudin-Sutter S, Dell-Kuster, Frei R, Bucher HC, Nuesch R, Factor associated with positive blood cultures in outpatients with suspected bacteremia, Eur J Clin Microbiol Infect, 2011, 30, 1615-1619.

8）渡辺 彰, 三木文雄, 大泉耕太郎, 力富直人, 古賀 宏延, 二木芳人, 草野展周, 齋藤 厚, 呼吸器感染 症に㧍ける新規抗微生物薬の臨床評価法策定の 根拠とその検証, 日本化学療法学会雑誌, 1998, 46, 498-505.

9) Andes D, Craig WA, Understanding pharmacokinetics and pharmacodynamics, application to the antimicrobial formulary decision process, Marcel Dekker New York, 65-88 (2005).

10) Lodise TP Jr, Lomaestro B, Drusano GL, Piperacillintazobactam for Pseudomonas aeruginosa infection: clinical implications of an extended-infusion dosing strategy, Clin Infect, 2007, 44, 357-363.

11) Yost RJ, Cappelletty DM; RECEIPT Study group, The Retrospective Cohort of Extended-Infusion Piperacillin-Tazobactam (RECEIPT) study: a multicenter study, Pharmacotherapy, 2011, 31, 767-775. 